\title{
Norsk laboratoriekodeverk - hvor ble det av visjonene?
}

\author{
Norsk laboratoriekodeverk skulle sikre entydig kommunikasjon mellom rekvirenter og laboratorier. Dette \\ skulle løfte kvaliteten på laboratoriemedisinske tjenester i Norge og passe inn i visjonen om én innbygger - \\ én journal. Hvorfor ble det aldri slik?
}

\author{
Andreas Austgulen Westin \\ andreas.westin@stolav.no \\ Astrid Louise Wester \\ Asbjørg Stray-Pedersen \\ Kari Løhne \\ Ying Chen \\ Richard W. Olaussen
}

I 2003 vedtok Stortinget at det skulle utvikles et felles klassifikasjonssystem for offentlig og privat laboratorievirksomhet i Norge (1). Sosial- og helsedirektoratet (senere Helsedirektoratet, nå Direktoratet for e-helse) fikk i oppdrag å styre og koordinere det nødvendige utviklingsarbeidet. Kodeverket fikk navnet Norsk enhetlig kodeverk for laboratorietjenester (NEKLAB) (2), og ble i 2013 forenklet og omdøpt til Norsk laboratoriekodeverk (NLK) $(3,4)$. Kodeverket ble gjort obligatorisk i norske laboratorier fra 1. oktober 2014 (5).

\section{Nasjonal oversikt}

Formålet med Norsk laboratoriekodeverk var først og fremst å sikre entydig kommunikasjon mellom rekvirenter og medisinske laboratorier ved bestilling av og svar på laboratorieanalyser og -undersøkelser. Det hadde lenge vært et problem at ulike laboratorier i Norge kunne operere med ulike navn for samme analyse, for eksempel «hvite», «leukocytter» og «leuk», og at det også manglet unike identifikatorer («analysekoder») for hver enkelt analyse.

Med Norsk laboratoriekodeverk ønsket man å oppnå en felles nasjonal oversikt over alle analyser og undersøkelser, med entydige navn og standardisert felles kodesetting på tvers av de seks laboratoriemedisinske fagområdene. Kort sagt: én analyse ett navn - én kode.

Alle de seks laboratoriemedisinske fagmiljøene, medisinsk biokjemi, medisinsk mikrobiologi, medisinsk genetikk, klinisk farmakologi, patologi og immunologi og transfusjonsmedisin, ønsket initiativet til et entydig og standardisert felles faglig kodeverk velkommen.

Så hvorfor ble det aldri slik?

\section{Feilslått prosjektledelse}

Oppgaven Helsedirektoratet påtok seg - med å utvikle og implementere Norsk laboratoriekodeverk - er særdeles krevende og komplisert. Ingen land har tidligere innført et obligatorisk felles laboratoriekodeverk som omfatter alle laboratoriefag. Et slikt pionérarbeid krever både god planlegging, solid forankring i foretakene, en romslig tidsplan, hyppig og tett oppfølging, kvalifiserte rådgivere, god informasjonsflyt, høye faglige ambisjoner, nøye koordinering på tvers av fagene, god kvalitetskontroll og evne og vilje til å lytte til innspill fra involverte

\section{«Fagmiljøenes tillit til Direktoratet for e-helse som kodeverksforvalter er sterkt svekket»}

aktører. Dessverre har Helsedirektoratets håndtering vært utilstrekkelig på alle disse punktene.

Det internasjonale kodeverket man tok utgangspunkt i og ønsket å innføre i Norge, var primært utviklet for medisinske biokjemiske analyser (6). Det var ikke tilpasset andre laboratoriespesialiteter, norsk språk eller norsk laboratorietradisjon. Fagmiljøene påpekte tidlig denne utfordringen og gjentok kritikken da første versjon av kodeverket ble publisert i 2013 (7). De anbefalte Helsedirektoratet å tilknytte seg kompetanse fra de seks laboratoriefagene for å koordinere en strukturert gjennomgang med faglig og språklig systematisering av Norsk laboratoriekodeverk, og å utforme en romslig og realistisk tidsplan for dette arbeidet $(7,8)$. Disse rådene ble ikke tatt til følge. Tvert imot ble kodeverket gjort obligatorisk og skulle implementeres på et tidspunkt da det var langt fra ferdig utviklet verken for faglige, tekniske eller økonomiske formål (5).

Denne formen for neglisjering av fagmiljøenes innspill har dessverre vært en rød tråd i prosjektledelsen av Norsk laboratoriekodeverk. Det samme skjedde da Helsedirektoratet lovte fagmiljøene å ta regi på utviklingen av en tverrfaglig tabell over analysemetoder som skulle nyansere forskjellene i resultater når samme analyse var utført med ulike analysemetoder (9-11). Hele dette prosjektet ble plutselig skrinlagt uten begrunnelse (12-14), i strid med en unison anbefaling fra fagmiljøene. Konsekvensen av dette grepet er blant annet at vi nå har et kodeverk som ikke kan benyttes for en god økonomisk refusjonsordning $(15,16)$, men som Helsedirektoratet likevel dessverre planlegger brukt til dette formålet (17).

Disse sakene, og mange flere av lignende karakter, gjør at fagmiljøenes tillit til Direktoratet for e-helse som kodeverksforvalter er sterkt svekket.

\section{Status i dag}

I dag, tre år etter at Norsk laboratoriekodeverk ble gjort obligatorisk og snart to år etter at det ble erklært implementeringsklart, har kodeverkets arkitektur fortsatt grunnleggende mangler som gjør at det ikke ivaretar alle laboratoriefagene. Det finnes ingen definert praksis for navnesetting av analyser som tar hensyn til de ulike laboratoriefagenes behov (18-20), ingen differensiering av analyser på grunnlag av analysemetoder (9-11), og ingen nasjonal standardisering av svarutgivelser (20). Kodeoversikten, som finnes på Helsedirektoratets hjemmeside (4), er ustrukturert og full av feil (21). Innmelding av koder skjer uten fagspesifikk gjennomgang og kvalitetssikring (22). Kodeverket har heller ikke tilstrekkelige faglige skillelinjer og korrekt sortering av analysene som inngår $(8,21)$. Dette gjør det svært vanskelig, både for Direktoratet for e-helse og fagmiljøene, å kvalitetssikre innholdet. Det er for øvrig beskrivende for prosjektledelsen at det første tverrfaglige arbeidsmøtet for kodeverket, med alle seks laboratoriefag til stede, ble avholdt først i 2016, over ti år etter arbeidet med kodeverket begynte, og over to år etter at det ble implementert (23).

I tillegg til de overordnede og systematiske manglene er det også store mangler innenfor flere av de seks fagområdene. For medisinsk 
genetikk og patologi vurderes det eksisterende kodeverket som så mangelfullt at fagmiljøene nylig anbefalte å slette eksisterende koder og begynne forfra igjen med en helt ny

\section{«Denne formen for}

\section{neglisjering av fagmiljø- enes innspill har dess- verre vært en rød tråd»}

struktur (23). For klinisk farmakologi avdekket en nylig gjennomgang av kodeverket så grove og omfattende feil at fagmiljøet nå fraråder laboratoriene å bruke Helsedirektoratets søkemotor og kodeoversikt som oppslagsverk (21). I tillegg har laboratoriene selv påpekt svakheter i kodeverket som kan utgjøre en trussel mot pasientsikkerheten (24). Likevel har Helsedirektoratet nå valgt å ta kodeverket over i det de kaller en vedlikeholdsfase (25), der fagmiljøenes rolle bagatelliseres og marginaliseres om mulig enda mer enn tidligere (26).

\section{Hvorfor må vi kjempe for selvfølgeligheter?}

Et prosjekt som tar sikte på å sikre nøyaktighet i faglig kommunikasjon innen flere spesialfelt er omfattende og krevende, og det sier seg selv at de som er de fremste forvalterne av den faglige spesialkompetansen etter årelang utdanning og erfaring, også nødvendigvis må være de som bidrar til å definere standarder og grunnleggende prinsipper for utforming og vedlikehold. Dette er så selvsagt at det er merkelig at det $\mathrm{i}$ det hele tatt må påpekes. Når man må argumentere for å bli hørt i slike saker, betyr det at adressaten verken forstår forutsetningene eller kompleksiteten innenfor området de er satt til å lede.

Ingen er tjent med økende gjensidig motsetning mellom fagmiljøene og kodeverksforvalter, aller minst brukerne av den tjenesten som skal utvikles. Nå er det opp til Direktoratet for e-helse å sørge for at tilliten mellom fag og forvaltning gjenopprettes.

\section{Sammen for et nasjonalt laboratoriekodeverk}

Ambisjonene for Norsk enhetlig kodeverk for laboratoriefagene $(1,2)$ og Norsk laboratoriekodeverk (3) var høye. Nå bør kodeverksforvalter hente disse ambisjonene frem igjen, blant annet ved å erkjenne at dette prosjektet er banebrytende i verdenssammen- heng, hvilket kodesystemets internasjonale samarbeidspartnere kan dra nytte av.

Vi trenger et nasjonalt laboratoriekodeverk, primært for å ivareta pasientsikkerhet og faglige hensyn, dernest til sekundærformål som statistikk og økonomi. Vi har allerede brukt for mye tid og krefter på en uryddig prosess. Direktoratet for e-helse må fra nå av sørge for inkluderende, samkjørte og godt forankrede prosesser. Først da kan vi få et funksjonelt Norsk laboratoriekodeverk i tråd med alle parters behov.

Alle dokumentene er sortert tematisk, og en oversikt over dem er tilgjengelig på nettsiden til Farmakologiportalen (27).

Vi takker styrene og ressurspersoner i våre seks fagmedisinske foreninger for nyttige innspill til manuskriptet.

\section{Andreas Austgulen Westin (f. 1977)}

er leder i Norsk forening for klinisk farmakologi. Han er overlege ved Avdeling for klinisk farmakologi, St. Olavs hospital.

Forfatter har fylt ut ICMJE-skjemaet og oppgir ingen interessekonflikter.

\section{Astrid Louise Wester (f. 1968)}

er leder i Norsk forening for medisinsk mikrobiologi. Hun er overlege ved Divisjon for smittevern, Nasjonalt folkehelseinstitutt

Forfatter har fylt ut ICMJE-skjemaet og oppgir ingen interessekonflikter.

\section{Asbjørg Stray-Pedersen (f. 1967)}

er leder i Norsk forening for medisinsk genetikk. Hun er overlege og forsker ved Nyfødtscreeningen, Oslo universitetssykehus.

Forfatter har fylt ut ICMJE-skjemaet og oppgir ingen interessekonflikter.

\section{Kari Løhne (f. 1961)}

er leder i Norsk forening for medisinsk biokjemi. Hun er overlege ved Avdeling for medisinsk biokjemi, Oslo universitetssykehus. Forfatter har fylt ut ICMJE-skjemaet og oppgir ingen interessekonflikter.

\section{Ying Chen (f. 1960)}

er leder i Den norske patologforening. Hun er overlege og avdelingssjef ved Avdeling for patologi, Akershus universitetssykehus.

Forfatter har fylt ut ICMJE-skjemaet og oppgir ingen interessekonflikter.

\section{Richard W. Olaussen (f. 1964)}

er leder i Norsk forening for immunologi og transfusjonsmedisin. Han er overlege ved Avdeling for kreftbehandling, Seksjon for celleterapi, Oslo universitetssykehus.

Forfatter har fylt ut ICMJE-skjemaet og oppgir ingen interessekonflikter.
Litteratur

1. St.meld. nr. 5 (2003-04). Inntektssystem for spesialisthelsetjenesten. Helsedepartement 2003. https://regjeringen.no/no/dokumenter/ stmeld-nr-5-2003-2004-/id197375/ (3.6.2016)

2. Informasjon om og korrespondanse angående NEKLAB: Bakgrunn og historikk. https://drive.google.com/file/d/OBxVUltNF2M xYi1MRjFsSHo3Qlk/view?pref=2\&pli=1 (3.6.2016).

3. Informasjon om og korrespondanse angående NLK: Oppstartshøring - brev fra Helsedirektoratet (31.1.2012). https://drive.google.com/file/d/ OBxVUltNF2M_xbk1wUWJhdzhpcFE/ view?pref=2\&pli=1 (3.6.2016).

4. Direktoratet for e-helse. Norsk laboratoriekodeverk (NLK). https://ehelse.no/ norsk-laboratoriekodeverk-nlk (3.6.2016)

5. Informasjon om og korrespondanse angående NLK: Innføring av NLK - informasjon fra Helsedirektoratet til fagmedisinske representanter (9.10.2013). https://drive.google.com/file/d/ OBxVULtNF2M_xbEZvVWVnOFFhODg/ view?pref=2\&pli=1 (3.6.2016)

6. Petersen UM, Dybkær R, Olesen H. Properties and units in the clinical laboratory sciences. Part XXII. The NPU terminology, principles, and implementation: A user's guide (IUPAC Technical Report). Pure Appl Chem 2012; 84: 137-65.

7. Informasjon om og korrespondanse angående NLK: Felles brev fra lederne i de seks fagmedisinske foreningene angående innføringen av NLK (26.3.2013). https://drive.google.com/file/d/ OBxVUItNF2M_xWVJ2ZDd4RkVsV3M/ view?pref $=2 \&$ pli $=1(3.6 .2016)$

8. NLK møtereferat - klinisk farmakologi: Klinisk farmakologi - møte 02 (11.3.2014) https://drive.google.com/file/d/OBxVUltNF2M xdDFwMXMtVG5rVjg/view?pref=2\&pli=1 (3.6.2016)

9. NLK møtereferat - medisinsk mikrobiologi: Medisinsk mikrobiologi - møte 02 (26.2.2014) https://drive.google.com/file/d/OBxVUltNF2M xekl2c3JlbkwwbXc/view?pref=2\&pli=1 (3.6.2016).

10. NLK møtereferat - medisinsk mikrobiologi: Medisinsk mikrobiologi - møte 04 (27.5.2014) https://drive.google.com/file/d/OBxVUltNF2M xR2ExN3Exc0V6ejg/view?pref=2\&pli=1 (3.6.2016).

11. NLK møtereferat - koordinerende gruppe: Koordinerende gruppe - møte 11 (27.1.2015). https://drive.google.com/file/d/OBxVUltNF2M xbTFIMOxaUnBhNEk/view?pref=2\&pli=1 (3.6.2016).

12. Informasjon om og korrespondanse angående NLK: NLK - metodetabell - referat fra møte mellom faggruppene og Helsedirektoratet (24.2.2015). https://drive.google.com/file/d/ OBxVUItNF2M_xN3RWVGcxWXI1ZjA/ view?pref=2\&pli=1 (3.6.2016).

13. Informasjon om og korrespondanse angående NLK: NLK - metodetabell - e-post til Helsedirektoratet med kommentarer angående referat og e-post om metodetabell (6.3.2015) https://drive.google.com/file/d/OBxVUltNF2M xb2tVUXpNYURjOXM/view?pref=2\&pli=1 (3.6.2016).

14. Informasjon om og korrespondanse angående NLK: NLK - metodetabell - svarbrev fra Helsedirektoratet til faggruppene (24.3.2015) https://drive.google.com/file/d/OBxVUltNF2M xTnAwdGFFZDI5aGs/view?pref=2\&pli=1 (3.6.2016)

15. Informasjon om og korrespondanse angående NLK: NLK - metodetabell og vedlikehold - brev fra Legeforeningen til Helsedirektoratet (8.5.2015) https://drive.google.com/file/d/OBxVUltNF2M_ $x U m w 2 T W N i Q V 83 W W 8 / v i e w ?$ pref $=2 \&$ pli $=1$ (3.6.2016).

16. NLK - ny refusjonsordning: brev fra patologene til Helsedirektoratet angående refusjonsordning (30.12.2015). https://drive.google.com/file/d/ OBxVUItNF2M xSTJiMy1RVGNWUIE/ view? pref $=2 \&$ pli=1 (3.6.2016).

17. NLK møtereferat - koordinerende gruppe: Koordinerende gruppe - møte 17 (23.11.2015). https://drive.google.com/file/d/OBxVUltNF2M $x d 1$ ljdm1EVFBBUm8/view? pref=2\&pli=1 (3.6.2016). 
18. NLK møtereferat - immunologi og transfusjonsmedisin: Immunologi og transfusjonsmedisin møte 06 (9.3.2015). https://drive.google.com/file/d/ OBxVUltNF2M_xUWpUakRRQmw50Tg/ view? pref $=2 \&$ pli=1 (3.6.2016)

19. NLK møtereferat - medisinsk biokjemi: Medisinsk biokjemi - møte 02 (20.3.2014). https://drive.google. com/file/d/OBxVUItNF2M xc3dQRmxhZG1PNEk/ view?pref=2\&pli=1 (3.6.2016).

20. NLK møtereferat - medisinsk biokjemi: Medisinsk biokjemi - møte 06 (19.3.2015)

https://drive.google.com/file/d/OBxVUltNF2M xVGNncOF5UUNVUOU/view?pref $=2 \&$ pli $=1$ (3.6.2016).

21. Informasjon om og korrespondanse angående NLK: Alvorlige avvik i NLK - brev fra klinisk farmakologisk referansegruppe til Helsedirektoratet (24.5.2016). https://drive.google.com/file/d/ OBxVUltNF2M_xb2F6dnFIVEhfeDA/ view? pref $=2 \&$ pli $=1(3.6 .2016)$

22. NLK møtereferat - klinisk farmakologi: Klinisk farmakologi - møte 06 (5.3.2015). https://drive.google.com/file/d/OBxVUItNF2M_ xaWZSWIZDRVZqOHM/view?pref=2\&pli=1 (3.6.2016)

23. NLK møtereferat - fagrådet: Fagrådet - møte 01 (10.5.2016). https://drive.google.com/file/d/ OB2L11rS_cHtCTOU5SlotWDhGWmc/ view? pref=2\&pli=1 (28.6.2016).

24. Informasjon om og korrespondanse angående NLK: Erfaringssamling Helse Sør-Øst - referat fra møte 29.2.2016 mellom Helse Sør-Øst og Direktoratet for e-helse. https://drive.google.com/file/d/ OBxVUltNF2M xMXhsSlpKem1JWWc view? pref $=2 \&$ pli=1 (3.6.2016)

25. Informasjon om og korrespondanse angående NLK: mandat for faglige referansegrupper høringsbrev fra Helsedirektoratet (16.10.2015) https://drive.google.com/file/d/0BxVUltNF2M xeXBUS1R6czhYWms/view?pref=2\&pli=1 (3.6.2016).

26. Informasjon om og korrespondanse angående NLK: mandat for faglige referansegrupper høringssvar fra Legeforeningen (7.12.2015). https://drive.google.com/file/d/OBxVUltNF2M xV2ZGdzg5T1dJRGc/view?pref=2\&pli=1 (3.6.2016)

27. Farmakologiportalen. Norsk laboratoriekodeverk (NLK) - møtereferat og brev.

http://farmakologiportalen.no/nlk-referat/ (28.6.2016).

Mottatt 10.6. 2016, første revisjon innsendt 28.6. 2016, godkjent 28.6. 2016. Redaktør: Ketil Slagstad.

Publisert først på nett. 